\title{
Genre Pedagogy and ELLs' Writing Skills: A Theme Analysis
}

\author{
Ayesha Asghar Gill ${ }^{1} \&$ Fauzia Janjua ${ }^{2}$ \\ ${ }^{1}$ University of Agriculture, Faisalabad, Pakistan. \\ ${ }^{2}$ International Islamic University, Islamabad, Pakistan. \\ Correspondence: Ayesha Asghar Gill, University of Agriculture, Faisalabad, Pakistan.
}

Received: April 1, 2020

Accepted: May 21, 2020

Online Published: July 20, 2020

doi: 10.5539/elt.v13n8p141

URL: https://doi.org/10.5539/elt.v13n8p141

\begin{abstract}
Coherent writing skill is an important prerequisite for academic success, especially at the tertiary level. This work studied the effect of four-month teaching intervention of genre pedagogy with Reading to Learn (R2L) approach for developing coherence in argumentative writing. It was implemented on 40 undergraduate Pakistani English Language Learners (ELLs). Pre-test evaluation informed learning gaps especially at theme choice and theme progression strategies in their argumentative writings. These gaps were addressed while planning the R2L teaching cycle of ELLs' experimental group. They were assisted through a process of scaffolding with an aim to enable them to write coherent argumentative essays independently after learning. Then functional analysis of lexical and grammatical features of their independent argumentative writings was conducted. Findings revealed that genre pedagogy had a significant effect on students' organization of argumentative writing. This study suggests genre pedagogy as a useful instructional technique, which can improve teaching and learning writing skills at the tertiary level in Pakistan.
\end{abstract}

Keywords: coherence, genre pedagogy, theme choice, theme progression, textual meta-function

\section{Introduction}

Writing skills acquisition is likely to be more demanding and laborious than other language skills (Ahmed 2010), specifically in one's second language context. For ELLs' the importance of writing skills cannot be negated as pointed out by Kroll (2008, pp. 230-231) who believed argumentative essay is the most frequently used writing form to get success in large scale tests such as the TOEFL, TESOL, IELTS to secure higher education admission. At the tertiary level, Students are expected to write mostly argumentative responses to a given prompt. In argumentative response, students are required to take a stance and provide reasons to support that stance (Martin 1989b). Despite, "reasoning, interpretation and explanation" as basic components of argumentation, the writer should be familiar with and should have the ability to use its lexical and grammatical resources to develop coherent and cohesive structure of argumentative writing to "persuade that the thesis is well formulated" (Martin 1989b). Therefore, coherent and cohesive writing becomes a parameter to successful argumentation for communication in an academic context. Coherence (organization of meaning) in the discourse, according to Halliday and Martin (1993), is achieved through textual meta-function, which has Theme-Rheme structure as its lexico-grammatical structures, in SFG framework. Various works propose (Cheng 2008; Christe \& Dreyfus 2007; Ho 2009) that to analyze the selection of theme-rheme and organization of theme progression (T/TP) is an effective framework to measure coherence in students' texts. T/TP organizes ideational and interpersonal meanings "into coherent and meaningful" (Droga \& Humphery, 2002, p. 11) written discourse. Moreover, it encodes semantic meanings and generic structures of the text. This work used SFL framework to study textual meta-function in Pakistani undergraduate ELLs' writings to analyze if it is possible to improve level of coherence in ELLs' argumentative writing through R2L genre pedagogy.

In Pakistani context, different studies (Dar \& Khan 2015; Haider 2012; Siddiqui, 2007) have indicated that major pitfalls in written responses of ELLs' are weak conceptual base in syntax, inadequate idea expansion, less relevant content selection, underutilization of topic sentence, inappropriate use of vocabulary and lack of coherence . Many efforts (Javed, Juan, \& Nazli 2013; Mahboob \& Talaat 2008) have been initiated to overcome ELL's writing problems at various levels such as, raising awareness about reading, extra course for improving tenses, grammar mechanics, teachers training, constructive feedback and change in examination system. Although, these steps did not bring any significant change in the written performance of ELLs, they provided an 
important insight into the teaching and learning of writing skills in the Pakistani context. On this information, it is likely to believe that teaching of English in Pakistan requires contemporary advances in the teaching of ELT, one of which is the utilization of a functional approach to language teaching. Functional approach targets on the usage of language to develop metacognitive, cognitive, linguistic and socio-affective strategies (Dar \& Khan 2015; Hyland 1990; Mahboob, 2013). It might be deduced that ELLs need to be engaged in different academic activities to improve their language performance by using functional instructional techniques in linguistic perspective as opined by Ilyas, Iqbal, and Fazal (2015) and Jillani (2004).

Probably in the Pakistani context, Functional techniques are not applied for teaching purposes yet. It is majorly used for literary texts, editorials, or multimodal text analysis. This research aims to apply genre pedagogy, which has already been implemented in the international educational context at all levels successfully for the last three decades (Gibbons, 2006; Martin, Christie, \& Rothery, 1987; Paltridge 2001), on Pakistani undergraduate ELLs. Although, aspects of language required for argumentative writing are several, this work focused to demonstrate the effectiveness of genre pedagogy for the development of coherence in argumentative written responses by comparing theme choice and theme progression in pre and posttest essays using experimental design. The researcher implemented genre pedagogy with the R2L teaching cycle for 4 months to foster Pakistani undergraduate ELLs' writings with explicit functional linguistic instructions proposed by Rose and Martin (2012).

\section{Literature Review}

Argumentative writing skills are essential for ELLs'. These skills support them to create their text by thinking and reflecting independently on the English language to fulfill the demands of academic context especially at the tertiary level. Various L2 writing pedagogies have been proposed to improve ELLs' writing proficiency. Genre pedagogy came into focus due to the limitations of the process approach, as it was unable to guide ELLs to construct a different type of written text. Genre pedagogy is designed through large scale action research projects and informed by various functional linguistic perspectives: genre and register theory of functional linguistics; Basil Bernstein educational sociology, Halliday's' language development, and Painters language learning insights. Genre approach provides meta-linguistic knowledge of English "language system" (Halliday \& Matthiessen 2014) and empowers ELLs by demonstrating explicitly different text types' generic features and meta-knowledge of coherence to organize diverse academic writing task by using disciplinary knowledge. Genre pedagogy as Paltridge (2007) endorsed raised ELLs' conscious about forms and patterns of language usage by explicitly describing distinctive recursive features related to different academic genres and provides a clear guideline for the coherent organization of different kinds of written texts by using a different linguistic framework.

In the international scenario, various attempts have been conducted on ELLs writing skills development. Cheng (2008) used genre pedagogy to improve undergraduate students' English narrative writing in Taiwan. He used different linguistic and functional features to improve their composition skills. Ho (2009) improved the review writing skills of a university student by using model review texts' for developing familiarity with its obligatory and optional sequence of stages, types of clauses, thematic choice, and theme progression, before asking her to write a review. Mello (2011) used Theme choice and thematic progression to improve the coherence of undergraduate ELL at the classroom level, conversely, there were only five sessions. Similarly, in the context of Sydney, genre pedagogy has been successfully experimented by various researchers for developing the writing skills of ELLs as international students at all levels of education. This study aims to highlight that despite having a low socio-economic and cultural background as compared to ELLs (international students) in European countries genre pedagogy has the potential to improve coherence in argumentative writing skills of ELLs in the L2 context: developing country like Pakistan. This research intends to explore the effect of Reading to Learn (R2L) genre pedagogy four-month intervention on improving coherence in argumentative writing skills by comparing theme choice and theme progression in pre and posttest essays. In light of reviewing the most related literature, the present work was concerned with analyzing the following sub research questions:

- What is the quantitative and qualitative effect of genre pedagogy intervention on theme choices in pre and posttest essays of Pakistani undergraduate ELLs?

- What is the quantitative and qualitative difference in thematic progression in pre and posttest essays of Pakistani undergraduate ELLs?

Written and oral discourse comprised of three meta-functions: ideational, interpersonal and textual (Halliday, 1985). Out of these three meta-functions, as Taboada (2006) delineates, textual meta-function is the one in which language as a discourse is realized to function as a complete message at the clause level. In message at clause level, theme is the first part "that which the clause is about" (Halliday \& Matthiessen 2014, p. 89). The theme is 
followed by Rheme, as Cummings (2003, p. 133) defines as a "part of the assembly of the new information that the text offers". Theme is the first element having a function in transitivity but it extends from the beginning of the clause. It means that theme comprised of a first linguistic element that may be participant, circumstance, or process, which is termed as a topical theme. The topical theme is classified into marked and unmarked themes. Halliday and Matthiessen (2014) proposed a cline of markedness on the possibility of different elements present in the initial position in a clause. The adverbial group or prepositional phrase serving as a circumstantial adjunct is most frequent and, complement are the least likely to be used as a marked theme. The unmarked theme is realized by the subject in a declarative clause, the operator in an interrogative clause, overt subject, or the verb in an imperative clause as cited in Jing (2015). Similarly, the topical theme may be headed by elements which have textual or interpersonal functions. They are called textual and interpersonal themes respectively. The textual theme is the combination of continuatives, conjunctions and conjunctive adjuncts (Halliday \& Matthiessen 2014). An interpersonal theme consists of vocatives, modal adjuncts, and mood markers.

The selection of a theme is important for a writer because it represents the writer's perception of the text as a message and indicates Theme progression. Similarly, theme progression besides being a guide to show the relationships between the theme and rheme of a clause and themes and rhemes of the following clauses, adds coherence in a text. Coherence is a semantic configuration of a written text. It shows how different elements are logically connected (Hinkel, 2017). According to Thompson (2004), there are two frequently used patterns of theme progression: linear progression and iterative progression. In the former pattern, the theme of a clause is derived from the theme of the earlier clause, and in the latter pattern, the theme has "repetition or co-reference of a theme in subsequent clauses" (Thompson 2005).

\section{Methodology}

An experimental design was employed to study the impact of genre pedagogy having Reading to Learn (R2L) approach across the curriculum (short stories), at the undergraduate level for four-months in the Pakistani context before and after its implementation. The experimental group was taught with different activities created on the R2L teaching cycle; the controlled group was taught with lecture-based teaching methodology. Teaching activities at the deconstruction stage of the R2L teaching cycle included analysis of target text lexical grammatical features associated with syntactic features, thematic choices, and cohesive ties. Next in joint construction stage researcher-students collaborative construction of argumentative essay modeled its generic stages, moves, and lexico-grammatical structures. It aimed to enable them to write argumentative writing independently. Then at the construction stage of the R2L teaching cycle, they wrote argumentative essays. These writings of 40 undergraduate Pakistani students of each group before and after genre pedagogy implementation was used as data. Thematic choices and thematic progression in pre and posttest of the controlled and experimental group were compared.

Firstly, for Functional Linguistic analysis, this research used a functional notion of theme choice at clause level by segmented the text into clauses, then each clause was divided into theme rheme; next, themes were labeled as textual, interpersonal or topical ones according to their function at clause level for quantitative analysis; secondly, it used thematic progression for exploring the change in organizational skills or unfolding of information, in the construction of the text. This research used t-unit for analysis of thematic progression. T-unit is defined as "an independent clause with all hypo-tactically related clauses which is dependent on it (Fries 1994, p. 229). Texts were segmented in T-units, then three type of theme progression was labeled for quantitative analysis. The three types of theme progression are Constant theme, simple linear and multiple themes/ split rheme as suggested by Paltridge (2000).

\section{Analysis and Discussion}

\subsection{Pretest Theme Choice Analysis}

According to Thompson (2004) selection of themes has a vital role in the construction of message and unfolding any language event (p.141). The researcher adopted on one hand Halliday's conceptual framework of thematic structure and Paltridge (2000) classification of thematic progression on the other hand. Theme choice orient the message towards the communicative goal of the genre. The researcher analyzed choices of theme and rheme of pre-test argumentative responses to assess problems in developing coherence in argument construction and text flow by following the suite of many research works (Arunsirot 2013). The thematic choices of 40 argumentative responses of ELLs' of both groups are shown under in table: 1 
Table 1. Theme Choices Pre-test Essays' Analysis

\begin{tabular}{lllll}
\hline Theme choice & Clauses & Topical & Interpersonal & Textual \\
\hline Experimental group & 1894 & 1510 & 47 & 337 \\
Control group & 2083 & 1640 & 53 & 390
\end{tabular}

Table 1 presents the maximum use of topical themes and minimum use of interpersonal themes. It is in accordance to ELLs' writings reported by different studies (Ebrahimi \& Ebrahimi 2012b; Green, Christopher, \& Larn 2000; Ho 2009; Lu 2013; Wei 2013a). Dominant use of topical themes indicated the common trend among writers to pick up the same theme over several clauses to add more information rather than to choose a theme by picking up rheme of the following clause to build argumentation. Secondly, there was only 47 and 53 pieces of evidence of interpersonal theme in experimental and controlled groups. It shows that ELLs did not use interpersonal themes as per genre requirement to take a position and to develop a dialogic relationship with the reader for persuasion. Thirdly, the scantiness in the usage of textual themes revealed that the majority of ELLs might not know textual theme function that does not only link the clause within the text and context but also guides readers to interpret a text (Arunsirot 2013). A few students deployed a variety of themes, which increased coherence in their text. Consider the following student exemplar 1: argumentative responses to assess problems in developing coherence in argument construction and text flow by following the suite of many research works (Arunsirot 2013). The thematic choices of 40 argumentative responses of ELLs' of both groups are shown under in table 1

Student Exemplar 1

\begin{tabular}{|c|c|c|c|c|}
\hline$c l$ & $\begin{array}{r}\text { Textual } \\
\text { theme }\end{array}$ & $\begin{array}{l}\text { Interpersonal } \\
\text { Theme }\end{array}$ & $\begin{array}{l}\text { Topical } \\
\text { Theme }\end{array}$ & Rheme \\
\hline 1 & As & & an ELLs & We do many bottom-up activities ........ \\
\hline 2 & For instance & & we & also use many top-down techniques as well \\
\hline 3 & When & & We & read, \\
\hline 4 & & & We & combine these two models \\
\hline 5 & Consequently & & reading & Strategically involves the interactive model. \\
\hline 6 & & & We & normally do three readings \\
\hline 7 & In First two & & We & use the top down model \\
\hline 8 & & & our & last detailed reading we use the bottom-up model \\
\hline 9 & So & & we & $\begin{array}{l}\text { can say that 'Interactive model is the best } \\
\text { description of what happens }\end{array}$ \\
\hline 10 & When & & we & Read \\
\hline
\end{tabular}

In Student exemplar 1 the textual theme "as an English Language Learners" clarifies the type of learners and work as a modifier for the topical theme "we". The conjunctive adjunct "for instance" at theme position helps the writer to add more information in the previous clauses and wh-relative "when" at theme place helps the writer to enhance the interaction of top-down and bottom-up model for better reading comprehension. In the last paragraph of the essay the conjunctive adjunct "consequently" at the onset place of clause helps the writer to prove the validity of the arguments to support the strategic interaction of both models and facilitates to realize a causal relationship. The other conjunctive adjuncts like "In First two" at thematic place enhanced the working of these models. The writer did not use generalized themes to show the assertion for an authoritative stance. "We" was used as a theme many times in several clauses, which made the essay more subjective rather than objective. Most of the themes of the essay were unmarked and pronominal.

\subsubsection{Pre-test Theme Progression}

Constant theme progression was used by the majority of ELL writers; as ELLs picked up a theme and reiterated it at the onset of each clause. Only five writers used linear theme progression, in which the subject matter in the rheme of preceding clause becomes the theme of the proceeding clause. For instance, student exemplar 1 used constant theme progression. The writer introduced "ELLs" in the theme of the 1st clause and then refer back to it by using the pronoun "we" 17 times. It made the text repetitive, static, and personalized and reduced the objective stance of the text. Similarly, in another exemplar, the writer used "I" three times at the theme position, 
which turned the text into a personal account. Some writers switched from the third person (they, it,) pronouns to 1st person pronouns (we, I) to refer back nominal groups to unfold the discussion. These patterns of textual meaning have been identified as a typical feature of ELLs writing skills by many researchers (Almaden 2006; Jalilifar 2010; Wang 2010). They attributed language transfer, language incompetence, and inefficient instructional techniques as a root cause of it. Hence, it is likely to assume that mostly ELLs were ignorant about the preferred style of academic writing which is "more distanced and more impersonal" as cited in Oliveira (2015).

Similarly, constant theme progression is not desired for an argumentative response. Rather it is more suitable for descriptions, classification, and narration (Alonso \& McCabe 2003). ELLs needs to learn academic argumentative style, which requires a higher percentage of simple linear theme progression because it enables the writer to deal with complex issues with expansion and explanation (Fries 1983), to defend and to oppose an idea for convincing the reader (Reid 1988) and to direct the reader's attention to take up the message according to his/her intentions (Schleppegrell, 2000).

Though, few students used theme choices efficiently to show impersonality and objectivity. They used nominal groups for topical themes such as "reading process", "students' interactive approach", and "students' fluency", then they refer back to these themes with pronouns such as 'it and this'. These theme choices showed the writer's detachment and unbiased opinion, which is more powerful to persuade readers around the main stance of the essay. It is presented under in table 2

Table 2. Pretest Response Simple Linear Progression Pattern

\begin{tabular}{llll}
\hline $\begin{array}{l}\text { Orientating } \\
\text { theme }\end{array}$ & $\begin{array}{l}\text { Clause } \\
\text { complex }\end{array}$ & Topical theme & Rheme \\
\hline 1 & The model & $\begin{array}{l}\text { Combines both surface structure systems, to build } \\
\text { meaning and memory for all learners. } \\
\text { use both knowledge of word structure and background } \\
\text { knowledge ...... }\end{array}$ \\
3 & Beaders & $\begin{array}{l}\text { who try an unknown word might use surface structure } \\
\text { system like letter-sound, knowledge to decode the } \\
\text { word... to decode same unknown word. }\end{array}$
\end{tabular}

Table 2 showed a simple linear theme progression pattern. The rheme of 1st clause complex "all learner" becomes the theme of clause complex 2 "reader". Then the rheme of clause complex 3 "they read" becomes the theme of clause complex 3 "being a student" to describe the interactive reading model process. However, some paragraphs of the same student exemplar did not follow theme progression as a text organizational tool.

The functional linguistic analysis of Pretest of both groups revealed ELLs underdeveloped textual organization skills about two aspects: theme choice and theme progression. There was greater use of topical unmarked theme $(78 \%)$ than textual theme $(18.5 \%)$ and interpersonal theme $(2 \%)$ in theme choice selection. Next, thematic progression was observed another learning gap. The majority of the writers used constant theme progression (93.75\%), however, some writers used simple linear progression (6.25\%).

In the light of pretest functional linguistic analysis, the researcher implemented genre-based Reading to Learn a methodology for four months. The next section describes the improvement in the argumentative writing skills of Pakistani undergraduate ELLs.

\subsection{Post-test Theme Choice Analysis of Both Groups}

Effective Theme-rheme construct shows a writer's command on disciplinary rhetorical practices (Tardy 2005, p. 325). In post-test essays, students made better thematic choices and developed efficient theme progression as compared to pre-test essays. It is presented in Table 3:

Table 3. Comparative Analysis: Theme Choices of Experimental and Controlled Group

\begin{tabular}{|c|c|c|c|c|c|}
\hline Experim & roup & & Controll & & \\
\hline Post-tes & atic Choices & & Post-text & tic Choices & \\
\hline Topical & Interpersonal & Textual & Topical & Interpersonal & Textual \\
\hline 1017 & 263 & 623 & 853 & 24 & 202 \\
\hline $45.54 \%$ & $11.77 \%$ & $27.37 \%$ & $44.91 \%$ & $1.26 \%$ & $10.63 \%$ \\
\hline
\end{tabular}


Table 3 presents the positive effect of genre-based reading to learn methodology on experimental group theme choice. It had worth mentioning increase in interpersonal (10.51\%) and textual themes (16.74\%) usage. However, there was no significant change in the topical theme $(0.63 \%)$.

Table 4. Comparative Analysis of Thematic Choices: Pre and Post-tests of Experimental Group

\begin{tabular}{llllllll}
\hline \multicolumn{2}{l}{ Post-test } & Thematic Choices & \multicolumn{5}{c}{ Pre-test Thematic Choices } \\
\hline $\mathrm{Cl}$ & Topical & Interpersonal & Textual & $\mathrm{Cl}$ & Topical & Interpersonal & Textual \\
2233 & 1017 & 263 & 623 & 1115 & 880 & 15 & 220 \\
$\%$ & 45.54 & 11.77 & 27.37 & $\%$ & 78.92 & 1.345 & 19.730 \\
\hline
\end{tabular}

Table 4 shows that in the posttest, ELLs construct their essays by smoothly unfolding their language event with a variety of thematic choices. In post-test, like pretest, students used the more topical theme but there was a significant increase in interpersonal (10.44 \%) and textual $(7.64 \%)$ themes usage. This improvement is in corroboration with Lu (2013) work on ESL, EFL, and English speaking Singaporean university students' argumentative essays and Wang (2010) claim, who endorsed that explicit instruction for theme selection by genre pedagogy is likely to improve textual meaning and cohesion in ELLs' writings.

Topical themes usually have participants, processes, or circumstances at the onset position of the clause. In the posttest, the topical theme slot is occupied by a refined grammatical structure: nominalization. Consider the following example:

Student Exemplar 2

"Rappaccini was an evil. His lifestyle and dress choice [topical theme: nominalization] was a suggestiveness for evil. His ambitions to change nature [topical theme: nominalization] results in devastation of human beings and animals. His fantasy for science [topical theme: nominalization] caused the death of her daughter. His poisons [topical theme: nominalization] were a barrier for lovers to be united."

The above exemplar 2 shows the maturity in the writing skills of the writer. The writer "thingify" the two abstract ideas "lifestyle and dress choice" with the help of nominalization "his lifestyle and dress choice" to capsulate the information into a single unit as evidence to support his argument. Nominalization helped the writer to produce coherence and cohesion inflow of information in a text (Halliday \& Matthiessen 2014).

Post-test essays had a prominent shift in the usage of interpersonal themes $(10.44 \%)$. It helped writers to develop a persuasive and convincing interaction with readers by developing arguments to mold readers' opinions around his stance on the given issue based on a literary text. Just as in the student exemplar 3 under:

Student Exemplar 3

"Yes, [interpersonal theme: polarity] Happy Prince shows the social evils of Victorian age. People were suffering with various social issues, which [interpersonal theme: Wh-relative] were seen by Happy Prince after his death such as people were suffering with poverty, Inequality, Exploitation, Hypocrisy. That's why [interpersonal theme: Wh-relative], happy prince sacrificed himself to bring revolution in the society."

Student exemplar 3 shows that the writer started with an interpersonal theme, an affirmative polarity "yes" and declarative mood for an authorial stance, "happy prince shows the social evils of Victorian age". Next, the writer gave evidence to support her stance. Finally, the writer finished the paragraph again with the interpersonal theme [interpersonal theme: Wh-relative] with a persuasive concluding line.

Likewise, posttest textual themes facilitate textual discourse by guiding readers through the text. Features such as logical connector $(3.731 \%)$, frame marker $(2.853 \%)$, and code glosses $(2.633 \%)$ of textual discourse to make their essays more reader-oriented. For instance in post-tests students used frame markers for different discourse stages as presented under in different students' exemplars:

4. "Overall,[textual meta-discourse: frame marker] his behavior towards the old man, the way he dismembered the dead body, moreover his strong senses verifies his symptoms of paranoia."

5. "Now, [textual meta-discourse: frame marker] she realized that whom she loved was gone mad. She thought that she should have to spend her whole life with her husband."

6. "It is innate in human being they forgot their memories because they have to keep their life on but if it does not happen and if it is not in the human nature then, [textual meta-discourse: frame marker] the life would be very difficult. Because, all the time remembering past memories will not make you able to live and you cannot do anything." 
The above frame marker used in students exemplars show as claimed by Morgan (2011) to announce their purpose. In exemplar 4 the frame marker "overall" sum up the arguments to link with the main claim that the protagonist had psychological problems. He was not mad. Next in the exemplar 5 and 6 the frame marker "Now" and "then" were used to show the order of sequence to communicate the thought in a logical manner.

Moreover, code glosses were also used by students in their post-test essays. They used as defined by Vande Kopple (1985) for "proper interpretation of elements, call attention." It is evident in the following student exemplars:

7. "Anyway, after the realization of truth he was greatly depressed. For example [textual meta-discourse: code glosses] when he faced the real world in bazar, he got hurt along with the distemper of mind in rage."

8. "In other words, [textual meta-discourse: code glosses] he was totally engaged in the strong inner feeling and emotions which he cannot understand, back to the point, nervousness created."

9. "Manhood is defined [textual meta-discourse: code glosses] by such traits which shows the quality of code hero. Hence, Nick is learning the code hero's character according to Hemingway."

The above exemplars show that exemplars 7 and 8 used code glosses "for example" and "in other words" to introduce reasons to support the arguments and in exemplar 9 writer used code gloss "defined" to highlight "manhood" as a key element of Hemingway' code hero. ELLs also used variety of linguistic choice as logical connectors such as "moreover", "therefore", "furthermore", "thus", "consequently", "now", "added to" and "also" for better organization of their academic argumentative responses.

Individually considering the above-cited categories of textual discourse, it is likely to conclude that students' post-test writings were improved, as they developed semantic relations for their different reasons with the main claim to support their stance for effective persuasion.

\subsubsection{Post-test Thematic Progression of Both Groups}

Butt, Fahey, Feez, Spinks, and Yallop (2000) argued that thematic progression explains how a writer has organized experiential and interpersonal meanings linearly and coherently. In post-test, there was a dominance of constant theme progression in both groups as it was in pre-test essays. It is presented under in table 5

Table 5. Analysis of Thematic Progression in Post-test Essays

\begin{tabular}{llllllll}
\hline \multicolumn{3}{l}{ Experimental group } & \multicolumn{5}{l}{ Controlled group } \\
\hline \multirow{2}{*}{ T-unit } & Constant & Linear & Derived & T-Unit & Constant & Linear & Derived \\
& Theme & Theme & Theme & & Theme & Theme & Theme \\
590 & 460 & 86 & 44 & 656 & 569 & 78.87 & 8.13 \\
& $77.966 \%$ & $14.572 \%$ & $7.457 \%$ & & $86.73 \%$ & $8.13 \%$ & $5.14 \%$ \\
\hline
\end{tabular}

Table 5 shows that even in posttest ELLs used more constant theme progression as compared to other types of theme progression in both groups, which is by Vietnamese oriental language group English argumentative essays reported by various researches conducted by Kaplan (2011) cited in Vu (2011). Vu (2011) argued that constant theme progression, which was considered as Vietnamese ESL learners' problems in L2 academic writing is not as a weakness; rather writers' different ways of structuring and developing their compositions due to different language and culture background. Thus, Pakistani ELLs like Vietnamese writers, as reasoned by Vu (2011), expressed their ideas indirectly in L2 by using a translation method while constructing English academic essays. Moreover, Thuy Le (2015) suggested that due to ELLs' L1 organizational pattern, it is difficult for them to follow zigzag theme progression pattern or linear TP in their L2 argumentative essays as per requirement. However, Post-test essays constant theme progression is different from Pre-test essays and, has different discourse features. Posttest essays had lexical variety as compared to lexical repetition in Pre-test essays. It is presented under in student exemplar 10: 
Student Exemplar 10

\begin{tabular}{|c|c|c|c|}
\hline $\begin{array}{l}\text { Orienting } \\
\text { theme }\end{array}$ & $\begin{array}{l}\text { Cl. } \\
\text { Complex }\end{array}$ & Theme & Rheme \\
\hline & \multirow[t]{2}{*}{1} & Love & Effects its victims badly \\
\hline & & $\mathrm{T} 1$ & $\mathrm{R} 1$ \\
\hline & \multirow[t]{2}{*}{2} & Passionate love & Undergoes the disaster by misconception of mind \\
\hline & & $\mathrm{T} 1$ & $\mathrm{R} 2$ \\
\hline & \multirow[t]{2}{*}{3} & Intense love & Is characterized by ...... to frustration \\
\hline & & $\mathrm{T} 1$ & $\mathrm{R} 3$ \\
\hline \multirow[t]{2}{*}{ Furthermore } & \multirow[t]{2}{*}{4} & disappointment & Dominates over protagonist.... \\
\hline & & $\mathrm{T} 2$ & R4 \\
\hline \multirow[t]{2}{*}{ Therefore } & \multirow[t]{2}{*}{5} & Awful effects & $<<$ Left by the love on its victims $>>$ could be seen \\
\hline & & $\mathrm{T} 1$ & R5 \\
\hline
\end{tabular}

Student exemplar 10 shows improved cohesion, coherence, and authorial stance of the text. The writer had effectively kept the flow of information by adding more detail or reasons to support his stance that "love affects its victim badly." Then in the above exemplar the theme "love" had a constant theme progression but the writer used different lexical resources such as "passionate love", "intense love" in clauses 1,2, and 3 . Then he used simple linear progression by using rheme 3 as the theme of clause 4 . Finally, he used again constant theme progression in clause 5 , however, the last clause became rheme of the theme presented in clause 1 , which attributed coherence to the text. It is presented in figure 1 below:

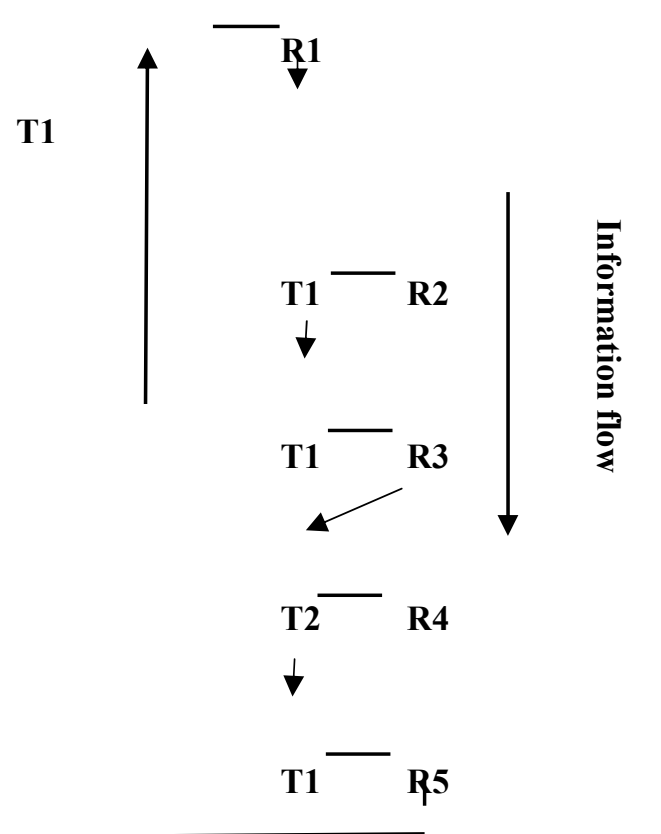

Figure 1. Student Exemplar Information Progression

The majority of writers followed the same organizational pattern for unfolding their information. Even in the constant theme progression, they developed their arguments effectively with appropriate flow of information and persuasion to convince the reader. Alonso and McCabe (2003) proclaimed that constant theme progression is not suitable for argumentation. However, on post-test essays functional linguistic analysis basis, it is likely to deduce that genre pedagogy had raised ELLs' critical awareness about the argumentative genre features. ELLs need to develop semiotic resources and focus on the nature of sociolinguistic interactions of the desired genre discipline as reasoned by Cummins (2008), besides understanding the content of the literary text and to take a position with 
the help of reasons for persuasive response. It needs more practice but the change in the post-test organization is worth mentioning, which could not be possible without genre-based reading to learn methodology.

\section{Conclusion}

Textual meanings have a paramount role in the construction of the interpersonal and ideational meaning of a written text with coherence. The comparative study of pre and post-test essay, after implementation of genre pedagogy with integrated reading and writing approach, revealed that Pakistani ELLs at the graduate level has improved many aspects of an argumentative written response to a literary text. Genre pedagogy provides a functional orientation of argumentative genre features for constructing their writings. In posttest out of three TP patterns, Constant theme progression was dominantly used due to different language and cultural backgrounds but with improved discourse features such as lexical richness and persuasive listing of reasons to maintain the flow of information. Similarly, in posttest interpersonal (11.799\%) and textual themes (20.44\%) usage had a significant difference.

Note: This research work is a part of the researcher's thesis "Integrating Critical Reading and Argumentative Writing: An experimental study" for the partial fulfilment of $\mathrm{PhD}$ degree.

\section{References}

Ahmed, A. H. (2010). Students' Problems with cohesion and coherence in EFL Essay Writing in Egypt: Different Perspectives. Literacy Information and Computer Education Journal, 1(4), 211-221. http:/doi.org/10.20533/licej.2040.2589.2010.0030

Almaden, D. (2006). An analysis of the topical structure of paragraph written by Filipno students. The Asia Pacific Education Research, 15(1), 127-153. https://www.dlsu.edu.ph/wp-content/uploads/pdf/research/journals/taper/pdf/200612/ALMADEN.pdf

Alonso, I. \& McCabe, A. (2003). Improving Text Flow in ESL Learner Compositions. TSEL Journal, 9(2). http://iteslj.org/Articles/Alonso-ImprovingFlow.html

Arunsirot, S. (2013). An Analysis of Textual Metafunction in the Thai EFL Students' Writing. Novitas- Royal Research on Youth and Language, 7(2), 160-174. http://www.novitasroyal.org/Vol_7_2/arunsirot.pdf

Butt, D., Fahey, R., Feez, S., Spinks, S. \& Yallop, C. (2000). Using Functional grammar : An Explorer's Guide 2nd Edition. National Centre for English Language Teaching and Resaerch, Sydney: Macquarie University.

Cheng, A. (2008). Analyzing Genre Exemplars in Preparation for Writing: The Case of an L2 Graduate Students in the ESP Genre Based Instructional Framework of Academic Literacy. Applied Linguistics, 29(1), 50-71. https://doi.org/10.1093/applin/amm021

Christe, F. \& Dreyfus, S. J. (2007). Letting the secret out: Successful writing in secondary English. Australian $\begin{array}{lllll}\text { Journal of Language } & \text { 235-247. }\end{array}$ https://search.informit.com.au/documentSummary; $\mathrm{dn}=774050298755648$;res=IELHSS

Cummings, M. (2003). The role of Theme and Rheme in contrasting methods of organization of texts. In C. Butler (Ed.). Dynamics of language use: Functional and contrastive perspectives (pp. 129-154). Amsterdam/Philadelphia: John Benjamins.https://doi.org/10.1075/pbns.140.12cum

Cummins, J. (2008). BICS and CALP: Empirical and theoretical status of the distinction. In B. Street \& N. H. Hornberger (Eds.). Encyclopedia of language and education (Vol. 2, pp. 71-83). New York: Springer.

Dar, M. F. \& Khan, I. (2015). Writing anxiety among public and private sectors Pakistani undergraduate university students. Pakisan Journal of Gender Studies, 10(1), 121-136. https://www.researchgate.net/publication/301361568_Writing_Anxiety_among_Public_and_Private_Sector s_Pakistani_Undergraduate_University_Students

Droga, L. \& Humphery, S. (2002). Getting Started with Functional Linguistics: Target Text. https://fejudeo.files.wordpress.com/2014/10/getting-started-with-functional-grammar.pdf

Ebrahimi, S. F. \& Ebrahimi, S. J. (2012b). Markedness in Writing: A case of EFL students. Theory and Practice in Language Studies, 2(4), 773-777. http://doi.org/10.4304/tpls.2.4.773-777

Fries, P. H. (1983). On the Status of Theme in English: Arguments from Discourse. In J. S. P. E. Sozer (Ed.). Micro and Macro Connexity of Text (pp. 1-38). Hamburg: Helmut Buske Verlag.

Fries, P. H. (1994). On theme, rheme and discourse goals. In M. Coultard (Ed.). Advances in Written Text Analysis. London: Routledge. 
Gibbons, P. (2006). Bridging Discourses in the ESL Classroom. New York: Continuum.

Green, C. F., Christopher, E. R. \& Larn, K. M. (2000). The incidence and effect on coherence of marked themes in interlanguage texts: A Corpus based enquiry. English for Specific Purpose, 19, 99-113. https://doi.org/10.1016/S0889-4906(98)00014-3

Halliday \& Martin, J. R. (1993). Writing Science: Literacy and Discursive Power. London: Falmer Press.

Halliday \& Matthiessen (2014). An introduction to functional grammar. New York: Routledge.

Haider, G. (2012). An insight into difficulties faced by Pakistani student writers: Implication for teaching of writing. Journal of Educational and Social Research, 2(3), 17-27. https://doi.org/10.5901/jesr.2012.v2n3p17

Ho, D. G. E. (2009). Systemic text analysis in the ESL writing classroom: Does it work? RELC Journal, 40(3), 333-359. https://journals.sagepub.com/doi/10.1177/0033688209343869

Hyland, K. (1990). A genre description of the argumentative essay. RELC Journal, 2(1), 66-78. Retreived from https://journals.sagepub.com/doi/abs/10.1177/003368829002100105

Ilyas, M., Iqbal, M. \& Fazal, S. (2015). Post/Graduate Academic Writing Problems: A Pakistani Case Image of research Literacy and writing Pedagogies for Masters and Doctoral Writers (pp. 389-406). Leiden: Brill Koninklijke. https://brill.com/view/book/edcoll/9789004304338/B9789004304338_001.xml

Jalilifar, A. (2010). Thematization in EFL students' composition writing and its relation to academic experience. RELC Journal, 31-45. https://www.researchgate.net/publication/249769012_Thematization_in_EFL_Students'_Composition_Writ ing_and_its_Relation_to_Academic_Experience

Javed, M., Juan, W. X. \& Nazli, S. (2013). A Study of Students' assessment in Writing Skills of the English Language. Online submission, $\quad 6(2), \quad$ 129-144. https://www.semanticscholar.org/paper/A-Study-of-Students'-Assessment-in-Writing-Skills-Javed-Juan/fd0 c30eb472f84f6d54250acbf77a258d951723c

Jillani, W. (2004). Conditions Under Which English is Taught In Pakistan: An Applied Linguistic Perspective. Sarid, 1-8. http://citeseerx.ist.psu.edu/viewdoc/download?doi=10.1.1.562.9996\&rep=rep1\&type=pdf

Jing, W. (2015). Theme and Thematic Progression in English Writing Teaching. Journal of Education and Research, 6(21), 178-187. https://www.iiste.org/Journals/index.php/JEP/article/view/24410

Kaplan. (2011). New Kaplan Gre Verbal Work Book. New York: Kaplan Publising.

Kroll, B. (2008). Exploring the Dynamics of Sceond Language Writing. USA: Cambridge University Press.

Lu, A. (2013). A functional grammar approach to analysing Asian students' writing. American Journal of Educational Research, 1(2),

1(2), 49-57. https://www.semanticscholar.org/paper/A-Functional-Grammar-Approach-to-Analysing-Asian-Lu/58004cff 961bf641ad4fofa42680853de2a04513

Mahboob, A. (2013). Genre based literacy programmes: contextualizing the SLATE project. Linguistics and Human Sciences, 7, 1-3.

Mahboob, A. \& Talaat, M. (2008). English language teachers and teacher education in Pakistan. TESOL. https://www.academia.edu/816230/English_language_teachers_and_teacher_education_in_Pakistan

Martin (1989b). Technically and abstraction: Language for the creation of specialized texts. In C. F (Ed.). Writing in School (pp. 36-44). Geelong: Victoria, Deaken University Press.

Martin, Christie \& Rothery. (1987). Social Processes in Education: A Reply to Sawyer and Watson (others). In I.Reid (Ed.). The Place of Genre in Learning: Current Debates (pp. 58-82). Center for Studies in Literary Education: Deakin University Press.

Mello, V. D. (2011). The influence of cohesion and coherence on text quality: A cross-linguistic study of foreign language learners' written production. In P.-K. E. \& \& S.-C. E. . (Eds.). Language in cognition and affect (pp. 111-131). Berlin: Springer.

Morgan, M. (2011). A corpus based investigation into the relationship between propositional content and metadiscourse in student essay writing. The University of Nottingham. http:/doi.org/10.1016/j.sbspro.2016.10.097 
Oliveira, L. C. D. (2015). A Systemic-Functional Analysis of English Language Learners' Writing. DELTA: Documentação de Estudos em Lingüística Teórica e Aplicada, 31, 207-237. http://dx.doi.org/10.1590/0102-4450364601799092306

Paltridge, B. (2000). Making Sense of Discourse analtsis. Gold Coast, Queensland: Antipodean Educational Enterprises.

Paltridge, B. (2001). Genre and the language learning classroom. Ann Arbor: University of Michigan Press.

Paltridge, B. (2007). Approaches to Genre in ELT. In J. Cummins \& C. Davison (Eds.). International Handbook of English Language Teaching (Vol. 15, pp. 931-943). USA: Springer.

Reid, J. (1988). Quantitative difference in English prose written Arabic, chinese, spanish and english writers. $\mathrm{PhD}$ dissertation. Colorado State University.

Rose, D. \& Martin, J. R. (2012). Learning to Write, Reading to Learn: Genre, Knowledge and Pedagogy in the Sydney School. London: Equinox.

Schleppegrell, M. (2000). How SFL can inform writing instruction: the grammar of expository essays. Revista Canaria de Estudios Ingleses, 40, 171-188. https://dialnet.unirioja.es/servlet/articulo?codigo $=80150$

Siddiqui, S. (2007). Rethinking education in Pakistan: Perceptions, practices, and possibilities. United States: Paramount Publishing Enterprise. https://doi.org/10.22555/joeed.v2i2.447

Tardy, C. M. (2005). It's like a story":Rhetorical knowledge development in advanced academic literacy. Journal of English for Academic Purposes, 4(1), 325-338. https://doi.org/10.1016/j.jeap.2005.07.005

Thompson, J. (2005). Theme analysis of narratives produced by children with and without specific language impairment. Clinical Linguistics and Phonetics, 19(3), 175-190. https://doi.org/10.1080/02699200410001698616

Thompson, L. W. (2004). Literacy Development for English language learners: Classroom Challenges in the NCLB Age. Monterey, CA: CTB: McGraw Hill. https://www.semanticscholar.org/paper/Literacy-Development-for-English-Language-Learners\%3A-Thomp son/c0779b536ab88bc1afae4bad2987f7fe226ba5ba

Thuy Le, D. (2015). Using Theme-Rheme to Analyze ESL / EFL Learners' Academic Writing. TESOL. http://www.vnseameo.org/TESOLConference2015/Materials/Fullpaper/Ms.\%20Le\%20Thuy\%20Dzuong.p df

Vande Kopple, W. J. (1985). Some Exploratory Discourse on Metadiscourse. College Composition and Communication, 36(1), 82-93. https://www.jstor.org/stable/357609?seq=1\#metadata_info_tab_contents

Vu, H. L. (2011). Non-native argumentative writing by Vietnamese learners of English: A contrastive study: Pro Quest Dissertations and Thesis. https://repository.library.georgetown.edu/bitstream/handle/10822/553147/hoVu.pdf;sequence=1

Wang, X. W. (2010). TP pattern and coherence in English writing: Analysis of TEM-4 writing papers. Foreign Language Research, 2, 103-106. http://en.cnki.com.cn/Article_en/CJFDTotal-OUTL201002024.htm

Wei, J. (2013a). Corpus based research on the development of theme choices in Chinese learners' English speech. $\begin{array}{lllll}\text { Journal of eEducation and } & \text { Practice, }\end{array}$ https://www.academia.edu/14866938/Corpus-based_Research_on_the_Development_of_Theme_Choices_i n_Chinese_Learners_English_Speech

\section{Copyrights}

Copyright for this article is retained by the author(s), with first publication rights granted to the journal.

This is an open-access article distributed under the terms and conditions of the Creative Commons Attribution license (http://creativecommons.org/licenses/by/4.0/). 